\title{
ANALYSIS OF FACTORS AFFECTING THE PRODUCTION OF CASHEW IN WENCHI MUNICIPALITY, GHANA
}

\author{
C. A. Wongnaa ${ }^{1}$
}

\begin{abstract}
The study considered the determinants of cashew production with special reference to cashew production in Wenchi Municipality of Brong-Ahafo Region of Ghana. Data collection was through well structured questionnaire administered on 140 respondents selected through random sampling technique. The methods of analysis used were descriptive statistics and production function analysis using the Ordinary Least Square (OLS) criterion to estimate the parameters of the production function. Results showed that majority of the farmers were ageing and $55.7 \%$ of them have a maximum of five years of cashew farming experience. Also there was high level of illiteracy as about $61.4 \%$ of total respondents have no formal education. Farming was majorly on subsistence level as the mean farm size was 3.33 acres. Results further showed that farm size, fertilizer, pesticides, pruning, education and contact with extension officers are positively related to cashew output while labour and years of experience are inversely related.
\end{abstract}

Key words: Cobb-Douglas Production function, Ordinary Least Square, Cashew farming

\section{INTRODUCTION}

Agriculture is the predominant sector in Ghana's economy. In 2008, agricultural activities contributed to $33.6 \%$ of Gross Domestic Product (GDP), employed about $60 \%$ of the labour force, and accounted for $54 \%$ of foreign exchange earnings. The sector itself is composed of five subsectors, namely crops other than cocoa, livestock, fisheries and forestry. However, non-traditional crops, such as pineapple, mango and cashew nuts, are increasingly of importance to the Ghanaian economy (MOFA, 2007).

Cashew is one of the non-traditional export crops being given the necessary boost by the government of Ghana. Cashew has a long history as a useful plant and only in the present century it has become an important tropical tree crop. The earliest reports of cashew are from Brazil (Mitchell and Mori, 1987). Cashew (Anacardium occidentale linn) is one of the important tree-nut crops, ranking third in international trade after hard nuts and almonds (MOFA, 2007).

The first ever recorded exports of cashew nuts from Ghana was in 1991, amounting to 15 metric tonnes. In 1997, export volumes rose to 3,571 metric tonnes. According to the Ghana Export Promotion Council, 2002, the country exported 3,893 metric tonnes of cashew valued at $\$ 1,450,306$. This export figure increased by $79.15 \%$ in 2003 to 6,338 metric tonnes, which was valued at $\$ 1,598,636$. Annual export of raw nuts reached 47,000 metric tonnes in 2006, contributing approximately US\$ 23 million in foreign exchange earnings. This figure is considered very small when compared 
with world excess demand of 430,000 metric tonnes of raw nuts, valued at US\$270 Million, and growing at a rate of $5-8 \%$ per annum. It is therefore obvious that demand continuous to exceed supply; meanwhile there are many cashew farmers in Ghana and their productivity is on the lower side (MOFA, 2007). This study was designed to analyse the determinants of cashew production in Wenchi Municipality of Brong-Ahafo Region of Ghana.

\section{MATERIALS AND METHODS}

\section{Study area and Data Collection}

The study was carried out in the Wenchi Municipality in the Brong-Ahafo Region of Ghana as it is the major cashew production zone in Ghana. The study area lies between latitudes $7^{\circ} 27 \mathrm{~N}$ and $8^{\circ} 30 \mathrm{~N}$ and longitudes $1^{\circ} 30 \mathrm{~N}$ and $2^{\circ} 36 \mathrm{~W}$. The Wenchi Municipality occupies an area of 7,619.7 square kilometres and a population density of 5-20 persons per square kilometre. The study used both primary and secondary data. Primary data was mainly cross-sectional. It was collected from 140 cashew farmers randomly selected from lists of cashew farmers in the following farming communities: Akrobi, Awisa, Nkonsia and Abotareye, the 2009-2010 production season. The communities were purposively selected based on the level of cashew production. In each community 35 cashew farmers were randomly selected. Variables included in the questionnaire were: initial capital outlay or establishment cost, area of land under cashew cultivation, labour input in land preparation, planting, weeding, fertilizer, pesticide application and harvesting, the quantities of pesticides and fertilizer used in cashew cultivation. Others include farmer's age, farmers' educational level, gender, whether or not farmers pruned their cashew trees, whether or not farmers used improved seeds, household size, farmers contact with extension workers, economic part of cashew sold, farming experience and sources of finance. Also the study made use of secondary data obtained from the internet, academic journals, libraries and the Ministry of Food and Agriculture (MOFA).

\section{Conceptual framework}

The economic model commonly used to determine the relationship between the various factors and the output in agriculture is production function model. The production function of any farmer is determined by resource availability of the farmer. In agriculture, the production inputs consist of land, labour and capital as the basic factors of production. The expected relationship between output and land is that as more land is brought under production, output is increased (Malassis, 1975). The simplified form of production function is given by:

$Q=f\left(L \_d, K, L\right)$

Where $Q$ is the production output, which is a function of land $\left(L_{d}\right)$, the capital $(K)$ and the labour force $(L)$ used for the production of the same output. A production function may be defined as a mathematical equation showing the maximum amount of output that can be realized from a given set of inputs. The mathematical form of the Cobb-Douglas production function is given by:

$Q=A L^{\alpha} K^{\beta}$

Where $Q$ is the output, $A$ is the technology used in the production of output, $L$ is labour input, $K$ is capital input and and are elasticity. Alternatively, a production function can show the minimum amount of inputs that can be utilized to achieve a given level of output (Malassis, 1975). To find out the impact of these factors on farm level production of cashew on small-scale farmers in Wenchi Municipality, the functional relationship is specified. 
The econometric model is specified as follows

Specifications of the Empirical Model

OUTPUT $=f(F A M S, L A B, C A P, F E R T, P E S T$, $\left.E D U, E X P, E X T C, D_{1}, D_{2}, D_{3}, u\right)$

(3)

Where,

OUTPUT $=$ Cashew nut output (in kilogrammes of cashew nut)

FAMS $=$ Farm size (in acres)

$\mathrm{LAB}=$ Labour quantity (in man-days)

$\mathrm{CAP}=$ Physical capital (in Ghana cedis (Gh $\phi)$ spent on equipments)

FERT $=$ Fertilizer used (in litres)

PEST $=$ Pesticides used (in litres)

$\mathrm{EDU}=$ Educational level of farmer (in years of schooling)

$\mathrm{EXP}=$ Experience of farmer (in number of years in cashew farming)

$\mathrm{D}_{1}=$ Dummy for variety ( 1 for improved type and 0 for local type)

$\mathrm{D}_{2}=$ Dummy for pruning ( 1 for pruning and 0 for no pruning) and

$\mathrm{D}_{3}=$ Farmers' contact with extension officers, measured as a dummy ( 1 for extension contact and 0 for no extension contact)

$\mathrm{u}=$ stochastic error term. $\ln O U T P U T=\ln \beta_{0}+\ln \beta_{I} F A M S+\ln \beta_{2} L A B+$ $\ln \beta_{3} C A P+\ln \beta_{4} F E R T+\ln \beta_{5} P E S T+\ln \beta_{6} E D U$ $+\ln \beta_{7} E X P+\ln \beta_{8} \mathrm{D}_{1}+\ln \beta_{9} \mathrm{D}_{2}+\ln \beta_{10} \mathrm{D}_{3}+\mathrm{u}$

(4)

\section{Estimation techniques}

Using Ordinary LeastSquares(OLS)technique, the coefficients of the above variables were estimated. For the study to estimate with OLS, the Cobb-Douglas production function had to be a transformed model, to satisfy the Classical Linear Regression Model (CLRM), so as to come up with the usual assumption of Best Linear Unbiased Estimator (BLUE).

\section{RESULTS AND DISCUSSIONS}

\section{Descriptive Analysis}

Evidence from the descriptive analysis of socioeconomic characteristics of respondents in the study area in Table 01 shows that $61.4 \%$ of the sampled cashew farmers were males and $38.6 \%$ were females. The results show that more men are involved in cashew production in the Wenchi Municipality than women. This is consistent with the results of CASCA (2002) which revealed that most cashew trees or farms are owned by men $(60 \%)$ while the other $40 \%$ are divided amongst women $(10 \%)$, the family as a whole (15\%) and grandparents (15\%). It also shows that both men and women can take cashew production as a business and a source of employment. 
Table 01: Socioeconomic Characteristics of Cashew Farmers

\begin{tabular}{lll}
\hline Characteristic & Frequency & Percentage $(\%)$
\end{tabular}

Gender

$\begin{array}{lll}\text { Male } & 86 & 61.4 \\ \text { Female } & 54 & 38.6 \\ \text { Total } & 140 & 100.0\end{array}$

Age

$\begin{array}{lll}\leq 20 & 0 & 0.0 \\ 21-40 & 36 & 25.7 \\ 41-60 & 68 & 48.6 \\ 61-80 & 36 & 25.7 \\ \text { Total } & 140 & 100.0\end{array}$

Education

$\begin{array}{lll}\text { Illiterate } & 86 & 61.4 \\ \text { Primary } & 24 & 17.1 \\ \text { Middle School/JSS } & 15 & 10.7 \\ \text { SSS/Vocational/Technical } & 10 & 7.1 \\ \text { Post Secondary/Tertiary } & 5 & 3.7 \\ \text { Total } & 140 & 100.0\end{array}$

Pruning

Do pruning 74

52.9

Do not do pruning

66

47.1

Total

140

100.0

Cashew Varieties

$\begin{array}{lll}\text { Improved } & 44 & 31.4 \\ \text { Local } & 96 & 68.6 \\ \text { Total } & 140 & 100.0\end{array}$

Household Size

$\begin{array}{lll}1-5 & 81 & 57.9 \\ 6-10 & 40 & 28.6 \\ >10 & 19 & 13.5 \\ \text { Total } & 140 & 100.0\end{array}$

Farming Experience (Years)

$\begin{array}{lll}\leq 5 & 78 & 55.7 \\ 6-10 & 34 & 24.3 \\ 11-15 & 20 & 14.3 \\ >15 & 8 & 5.7 \\ \text { Total } & 140 & 100.0\end{array}$

Source: Field Survey data, 2010 
Table 01: continued

\begin{tabular}{lll}
\hline Characteristic $\quad$ Frequency & \multicolumn{2}{c}{ Percentage (\%) } \\
Sources of Finance & & 65.0 \\
Personal Savings & 91 & 7.1 \\
Friends & 10 & 6.4 \\
Relatives & 9 & 8.6 \\
Cooperatives & 12 & 12.9 \\
Bank Loans & 18 & 100.0 \\
Total & 140 & \\
Contact with Extension Officers & & 30.0 \\
Contact & 42 & 70.0 \\
No Contact & 98 & \\
Economic part of cashew sold & & 0.0 \\
Apple & 0 & 100.0 \\
Nut & 140 & 100.0 \\
Total & 140 &
\end{tabular}

Source: Field Survey data, 2010

The results of the study show that most cashew farmers in Wenchi Municipality are ageing since a greater percentage of the cashew farmers interviewed (74.3\%) were above forty (40) years and none of the respondents was below twenty (20) years. Very few cashew farmers in the municipality $(25.7 \%)$ were between the ages of twenty-one (21) and forty (40) years. Farmers in this age group constitute the very energetic youth and are likely to work effectively to increase their yields. The few number of youth involved in cashew production $(25.7 \%)$ could indicate that the future of the cashew industry, especially in the Wenchi Municipality is bleak. The youth are the future growers of the cashew crop and if cashew nut supply is to be sustained, there is the need for youth to be encouraged to go into cashew production. From the study, it was realised that a higher percentage of cashew farmers in Wenchi Municipality (61.4\%) are illiterate. Such farmers did not receive formal education. About $17.1 \%$ of cashew farmers in the Wenchi Municipality ended in the primary school while $10.7 \%$ of them were educated up to the Middle or Junior Secondary School level. Some cashew farmers in the municipality (7.1\%) had Senior Secondary School

education while very few of them (3.7\%) got to the Post Secondary and Tertiary level. The higher percentage of illiterate farmers could have negative impact on the adoption of new production technologies. Generally education is thought to create a favourable mental attitude for the acceptance of new practices especially of information-intensive and management-intensive practices (Waller et al., 1998; Caswell et al., 2001). Education is thought to reduce the amount of complexity perceived in a technology thereby increasing a technology's adoption. According to Ehler and Bottrell (2000), one of the hindrances to widespread adoption of especially Integrated Pest Management (IPM) as an alternative method to chemical control is that it requires greater ecological understanding of the production system.

The results of the study revealed that a greater percentage of cashew farmers in the Wenchi Municipality $(52.9 \%)$ pruned their cashew trees while $47.1 \%$ did not do pruning. The results show that most cashew farmers in Wenchi Municipality probably have identified pruning as a very important cultural practice in cashew production. There is however the need 
for increased awareness of the importance of pruning in cashew production since $47.1 \%$ of the respondents did not do pruning at all.

The results showed that only $31.4 \%$ of cashew farmers in the Wenchi Municipality used improved varieties of cashew while the rest $(68.6 \%)$ used local varieties.

The results of the study showed that cashew nut is the main product of the cashew crop of economic importance in Wenchi Municipality. Also, a greater proportion of cashew farmers in the Municipality (65\%) financed their production through personal savings. The distribution of the household size indicated that most cashew farmers in the Municipality $(57.9 \%)$ had a household size that ranged from 1 to 5 while the average farm size was found to be 3.33 acres. The study also revealed that $70 \%$ of cashew farmers in Wenchi Municipality have no access to extension service. Most studies analyzing access to extension service in the context of agricultural technology show its strong positive influence on adoption. In fact Yaron et al., (1992) show that its influence can counter balance the negative effect of lack of years of formal education in the overall decision to adopt some technologies. Finally, most cashew farmers sampled had less than five (5) years of experience in cashew production. This could have a negative impact on output.

\section{Cashew production function analysis}

From the regression results in Table 02, farm size, labour, fertilizer, pesticide, pruning, education and contact with extension officers were observed to affect cashew output significantly and hence are the determinants of cashew production in the study area. Farm size, labour and pesticides were significant at $1 \%$ whereas fertilizer and education were significant at 5\%. Pruning and contact with extension officers were also significant at $10 \%$. The $\mathrm{R}^{2}$ value for the regression is 0.840912 and this means that $84.1 \%$ of the variations in cashew output are explained by the factor inputs. Also from the F-statistic it can be concluded that the overall regression is significant at $1 \%$ significance level. The values of the coefficients indicate the elasticity of the various inputs to the output. Considering farm size, the elasticity value indicates that if land under cultivation is increased by $1 \%$, the yield of cashew would increase by $92.4 \%$. If quantity of fertilizer, pesticides, pruning, education and contact with extension officers increase by $1 \%$, yield of cashew would increase by $8.7 \%$, $4.3 \% .43 \%, 12.6 \%$ and $12.5 \%$ respectively, because they are positively related to cashew output. This is in line with the results of Goni et al., (2007) who conducted a study into the analysis of resource-use efficiency in rice production in the lake Chad area of Borno state, Nigeria and found out that a unit increase in the level of seed, farm size, and fertilizer will lead to 12.6, 127.2, and 20.5 percent changes in rice output respectively. Abang et al., (2001) also reported that education was positively related to the value of marginal product though not statistically important. This might be due to the fact that educated farmers were able to adhere to and adopt new farming technologies. Others such as Aderinola (1988), Aderinola and Kolawole (1996), Eremie and Akinwumi (1986) and Ojo (2000), investigated the productivity of sugar cane production, mechanized food crop farming, rice production and maize farming respectively and they found out that farmers' socio-economic characteristics including education and experience were significant determinants of agricultural production and profitability. Imoudu (1992) also showed that farm size is a significant determinant of maize output and profitability in OndoState. The results of the study are also in consonance with those of Ohajianya (2006) in Imo State, Nigeria, and Onyenweaku et al., (1996). Labour and years of experience however had negative coefficients indicating that an increase in labour and years of experience will lead to a decrease in yield and 
this corroborates Stephen et al., (2004), who studied on resource-use efficiency in cowpea production in North East Zone of Adamawa State, Nigeria and reported an inverse relationship between labour and output. The negative sign of years of experience is contrary to a priori expectation. This is probably due to the fact that farmers with long years of experience are used to obsolete methods of farming, traditional tools and species which do not encourage high output.

\section{CONCLUSION}

Findings from the study indicate that cashew farming in the municipality is a male dominant activity with the men making up $61.4 \%$ of the respondents sampled. Most of the cashew farmers in the study area $(70 \%)$ have no contact on a regular basis with extension agents. Also, a greater proportion of cashew farmers in the Municipality (65\%) financed their production through personal savings. That is most farmers do not receive financial assistance in the form of credit from formal sources. The results also showed that majority of the farmers were ageing and quite inexperienced in cashew production. Also, the level of illiteracy was very high among the respondents as about $61.4 \%$ of total respondents had no formal education while $17.1 \%, 10.7 \%, 7.1$ and $3.7 \%$ had primary, Middle School/JSS, secondary/ Vocational and tertiary education respectively. Respondents are majorly small-scale farmers with a mean farm size of 3.33 acres. Results further showed that variables such as farm size, fertilizer, pesticides, pruning, education and contact with extension officers are positively related to cashew output while labour and years of experience are inversely related. Farmers should be encouraged to use fertilizers and pesticides so as to increase productivity. Among other things, farmers should have more access to extension services in order to improve their knowledge of farm management. Also, the government should introduce the farmers to formal education through adult literacy education, evening classes and establishment of demonstration farms.

\section{Table 02: Estimates of the Production function analysis}

Dependent Variable: lnOUTPUT

\begin{tabular}{lllll}
\hline Variable & Coefficient & Std. Error & t-Statistic & Prob. \\
\hline $\mathrm{C}$ & 5.106303 & 0.739814 & 6.902142 & 0.0000 \\
$\ln \mathrm{n} A M S$ & 0.923613 & $0.188644^{* * *}$ & 4.896063 & 0.0000 \\
$\operatorname{lnLAB}$ & -0.022457 & $0.185277^{* * *}$ & 0.121206 & 0.0007 \\
$\ln \mathrm{AAP}$ & 0.043158 & 0.189123 & 2.456227 & 0.0289 \\
$\operatorname{lnFERT}$ & 0.087111 & $0.024699^{* *}$ & 3.526886 & 0.0226 \\
$\ln \mathrm{ESST}$ & 0.042582 & $0.018065^{* * *}$ & 2.357151 & 0.0099 \\
$\operatorname{lnEDU}$ & 0.125941 & $0.047278^{* *}$ & 2.663864 & 0.0187 \\
$\ln \mathrm{EXP}$ & -0.425361 & 0.012548 & 2.335458 & 0.1591 \\
$\ln \mathrm{D}_{1}$ & 0.222333 & 0.092272 & 2.409537 & 0.5174 \\
$\ln \mathrm{D}_{2}$ & 0.429783 & $0.163515^{*}$ & 2.628402 & 0.0796 \\
\hline $\ln \mathrm{D}_{3}$ & 0.125354 & $0.135458^{*}$ & 5.124535 & 0.0821 \\
\hline $\mathrm{R}$-squared & 0.840912 & Mean dependent var & 6.442207 & \\
& & F-statistic & 98.92029 & \\
\hline
\end{tabular}

Note: (***) Indicates significance at the $1 \%$ level. $(* *)$ indicates significance at the $5 \%$ level. $(*)$ indicates significance at the $10 \%$ level Source: Field Survey data, 2010 


\section{ACKNOWLEDGEMENT}

The authors are especially indebted to the staff of the Ministry of Food and Agriculture (Wenchi) for the information they provided about the cashew crop. They are also grateful to the respondent farmers, without whose cooperation the study could not have taken place.

\section{REFERENCES}

Abang, S.O., Ekpeni, E. and Usani, W.W. (2001). "Technical and Allocative Efficiencies of Small Scale Growers in five selected Local Government Areas of Cross River State", Global Journal of Applied Sciences., 7 (1): 102-106.

Aderinola, E.A. (1988): "Returns and Productivity Coefficients for selected Resources at Bacuta Sugar Estate, Nigeria”, Ahmadu Bello University Press Ltd, Zaria. Savana J. Environ. Social Sci., 9(1).

Aderinola, E.A. and Kolawole, J.O. (1996). "Profitability and Capacity Utilization of Rice Milling Enterprises in Ondo State, Nigeria”. Agro Search, 102: 15-28.

CASCA (Componente de Ajuda ao Sector de Caju - Support to the Cashew Sector) (2002). "Programme Proposal. Support to the cashew sector in Nampula Province, Mozambique." Ajuda de Desenvolvimento de Povo para Povo - Development Aid from People to People (ADPP), Associação Moçambicana para o Desenvolvimento Rural - Mozambican Association for Rural Development (AMODER) and Netherlands Development Organization (SNV).

Caswell, M., Fuglie, K., Ingram, C., Jans, S. and Kascak,C. (2001). "Adoption of Agricultural production practices: Lessons learned from the US. Department of Agriculture area studies project." Washington DC. US Department of Agriculture. Resource Economics Division, Economic Research service, Agriculture Economic Report No. 792.

Ehler, L.E and Bottrell, D.G. (2000). "The illusion of Integrated Pest Management. Issues in Science and Technology." Bell and Howell Information and Learning Company. pp. 61-64.

Eremie, S.W. and Akinwumi, J.A. (1986). "Profitability of Irrigated Rice Production in Nigeria", Rural Development in Nigeria, Federal Department of Agriculture, Lagos, Nigeria, 2(2): 95-104.

Goni, M., Mohammed, S. and Baba, B. A. (2007). "Analysis of Resource-Use Efficiency in Rice Production in the Lake Chad Area of Borno State, Nigeria." Journal of Sustainable Development in Agriculture \& Environment Vol. 3:31-37.

Imoudu, P.B., (1992). "Economics of Maize Production and Marketing in Ondo State of Nigeria", Unpublished Ph.D Thesis, Development of Agricultural Economics and Extension, FUTA, Akure, Ondo-State, Nigeria. 
Malassis, L. (1975), “Agriculture and the Development Process”. The UNESCO Press. Paris.

Mitchell, J.D and Mori. S.A. (1987). "The cashew and its relatives". Memoirs of the New York Botanical Garden English 42, 76.

Ministry of Food and Agriculture [MOFA] (2007). "Status of Ghana Cashew Industry." www. ghanacashewproducts.com.

Ohajianya D.O. (2006). "Resource use Efficiency of land Owners and Tenants in Food Crop Production in Imo State Nigeria." Journal of Sustainable Tropical Agricultural Research. Vol.17, PP.26-30.

Ojo, S.O., (2000). "Factor Productivity in Maize Production in Ondo-State, Nigeria”. School of Agriculture and Agricultural Technology, FUTA, Akure, Ondo State, Nigeria. Applied Tropical Agriculture., 5 (1): 57-63.

Onyenweaku, C.E, Obasi, P.C and Anyanwu, S.O. (1996). "Production Relationships Among Compound and Non-Compound Farmers in Imo State Nigeria." Journal of Applied Science in Southern Africa, 2(1): 31-36.

Stephen, J, Mshelia, S.I, Kwaga, B.T. (2004). "Resource-use Efficiency in Cowpea Production in the North-Eastern zone of Adamawa state, Nigeria." Department of Forestry and Wildlife Management, Federal University of Technology. Yola, Nigeria.

Waller, B.E., Hoy, C.W., Henderson, J.L, Stinner, B. and Welty, C. (1998). “Matching Innovations with Potential Users: A Case Study of Potato IPM practices." Agriculture, Ecosystems and Environment. Pp 203-215.

Yaron, D., Dinar, A. and Voet, H. (1992). "Innovations on Family farms: The Nazareth Region in Israel.” American Journal of Agricultural Economics. Pp 361-370. 